KAWISTARA

VOLUME 4

No. 3, 22 Desember 2014

Halaman 225-330

\title{
ISLAM YANG RAHMAT DALAM MEMBANGUN UMAT STUDI TERHADAP DAKWAH PAIF KABUPATEN SLEMAN
}

\author{
H.M. Kholili \\ Fakultas Dakwah dan Komunikasi UIN Sunan Kalijaga \\ Email: hmkholili@yahoo.com \\ Syamsul Hadi \\ Fakultas Ilmu Budaya \\ Universitas Gadjah Mada \\ Subejo \\ Fakultas Pertanian Universitas Gadjah Mada
}

\begin{abstract}
Islamic that mercy has been encouraging for his people, therefore Islamic concept that was delivered by Islamic preachers has given benefit and welfare of the inner and outer life. In fact, poor Muslim population reaches $23 \%$, while most of them have not been routinely practicing the tought of Islam. This paper aims to analyze the competence factor of preachers (PAIF) effect on the activity of preaching; and analyze the preaching components a PAIF affects to preaching effects. This research was conducted in Sleman Yogyakarta by using a mixed method of quantitative analysis that is supported by SEM analysis techniques. The research results showed that: a PAIF required to has competence in understanding the socio-cultural and communicate well so that he can design the preaching messages that fit to the needs of targeted community. Encouraging preaching activities can be organized through: setting the theme of preaching messages that support the needs of followers; presented by giving motivation; balancing the use of preaching methods and the preaching extension methods, as well as utilizing other forms of communication appropriately and optimally.
\end{abstract}

Keywords: Islamic mercy, build community, Sleman.

\begin{abstract}
ABSTRAK
Islam yang rahmat itu menggembirakan bagi umatnya, karena ajaran Islam yang disampaikan dai telah memberikan manfaat bagi kehidupannya dan mensejahterakan lahir batin. Kenyataan, penduduk muslim miskin mencapai $23 \%$, sementara sebagian mereka belum rutin mengamalkan ajaran Islam. Tulisan ini bertujuan menganalisis sejauhmana faktor kompetensi dai (PAIF) berpengaruh pada kegiatan dakwah; dan menganalisis sejauhmana komponen kegiatan dakwah PAIF berpengaruh terhadap efek dakwah. Penelitian ini dilakukan di Sleman Yogyakarta dengan menggunakan mixed method yang ditopang analisis kuantitatif dengan tehnik analisis SEM. Hasil penelitian menunjukkan bahwa: Seorang PAIF dituntut memiliki kompetensi memahami sosial budaya dan berkomunikasi secara baik sehingga dia dapat merancang pesan dakwah yang sesuai dengan kebutuhan masyarakatnya. Kegiatan dakwah yang menggembirakan dapat diusahakan dengan: menetapkan tema pesan dakwah yang menunjang bagi kebutuhan jamaah; disajikan dengan sajian yang memberi motivasi; menyeimbangkan penggunaan metode dakwah penerangan dan metode dakwah penyuluhan; serta memanfaatkan bentuk-bentuk komunikasi secara tepat dan maksimal.
\end{abstract}

Kata Kunci: Islam rahmat, Membangun umat, Sleman. 


\section{PENGANTAR}

Penduduk Sleman berjumlah 1.066.673 jiwa. Mereka (23\%) berada pada kondisi miskin (BPS Sleman, 2009: 54). Adapun penduduk beragama Islam ada sekitar $90 \%$ dari pemeluk agama yang ada (BPS Sleman, 2009: 119). Ketika proporsi penduduk miskin mencapai $23 \%$ dari jumlah penduduk yang ada, maka jumlah penduduk beragama Islam yang miskin diperkirakan berjumlah 220.801 penduduk.

Penduduk muslim Sleman secara keseluruhan adalah menjadi sasaran kegiatan dakwah atau penyuluhan agama yang adadi Kabupaten Sleman. Para Penyuluh Agama Islam Fungsional (PAIF) mempunyai tugas berdakwah dalam pengertaian memberikan pembinaan keagamaan dan pembinaan berkehidupan yang agamis pada jamaah kelompok binaannya. Akan tetapi, pembinaan yang dilakukan para PAIF yang berupa pengajian sebenarnya lebih kepada ceramah yang sifatnya memberi informasi ajaran keagamaan semata (Wawancara, "Skn" PAIF, 2012). Berdasarkan cacatatan yang ada pada MUI Sleman (2005: 35) bahwa, secara umum, kuantitas dan kualitas dai masih belum memadai, tidak terkecuali para dai PAIF. Metode dakwah yang digunakan masih seputar pengajian dan ceramah, sedangkan pesan dakwahnya di seputar aqidah dan ibadah dengan sarana dakwah yang sederhana; sementara jamaah sasaran dakwahnya masih minim pengetahuan dan pengamalan keislamannya.

Setiap Penyuluh Agama dalam menunaikan tugas tidak boleh hanya terpaku pada pengetahuan yang telah dimilikinya saja, melainkan harus kaya dengan pengetahuan dan wawasan sosial kemasyarakatan agar penyuluhan yang disampaikan memberikan nilai tambah bagi masyarakat (umat) dan dirasakan sebagai sesuatu yang memberikan solusi terhadap prbolema kehidupan mereka (Depag DIY, 2005: 1-2), sehingga masyarakat (umat) dapat hidup sejhatera lahir batin.

Kegiatan dakwah sebagai proses komunikasi, pertama, penetapan tema pesan, penyajian pesan, penggunaan metode dan pemanfaatan bentuk komunikasi adalah beberapa hal yang harus dikuasai oleh setiap Penyuluh Agama. Pengembangan PAIF harus diarahkan kepada munculnya kompetensi yang memadahi sehingga mereka dapat melaksanakan dakwah secara proporsional (atas komponen dakwah yang ada) dan profesional (mampu dan terukur). Oleh karena itu, penelitian ini menjadi menarik dan penting untuk dilakukan.

Tulisan ini bertujuan menganalisis sejauhmana kompetensi PAIF berpengaruh pada kegiatan dakwah yang meliputi: penetapan tema pesan, penyajian pesan, penggunaan metode dan pemanfaatan bentuk komunikasi. Kedua, menganalisis sejauhmana kegiatan dakwah PAIF berpengaruh terhadap efek dakwah.

\section{Konsep Dakwah Rahmatan Lil 'Alamin}

Ajaran Islam sebagai rahmat $(Q S, A l-$ Ambiyaa, 21: 107) adalah ajaran Islam yang memberikan manfaat bagi kehidupan manusia ... kehidupan yang sejahtera lahir batin (Suisyanto, 2006: 93). Terkait dengan fungsi kerahmatan ini, ajaran Islam yang masih normatif harus dijabarkan ke dalam konsep yang dapat diimplementasikan dalam kehidupan nyata untuk mencapai kebahagian dan kesejahteraan (Suisyanto, 2006: 94; QS, al-Baqarah, 2: 201; an-Nisa, 4: 134; Yunus, 10: 64). Ajaran Islam sebagai rahmat ini melahirkan konsep ajaran Islam yang menyejahterakan dan membahagiakan manusia.

Kedatangan Islam yang rahmat, rahmatan, tentu akan merupakan berita gembira (basyiran) bagi seluruh manusia, khususnya manusia yang menjadi target audiensnya, “...hanya saja kebanyakan manusia tiada mengetahui". (QS, Saba, 34: 28). Bagaimana ajaran Islam yang benar dan baik itu bisa dipahami dan diamalkan oleh umat manusia, diperlukan aktivitas yang bernama dakwah. Oleh karenanya diperlukan suatu konsep Dakwah yang Menggembirakan.Dakwah yang menggembirakan dapat dilakukan dengan empat langkah sebagai berikut: 
Pertama,Seorang dai dalam melakukan dakwah menjadikan upaya menyejahterakan dan membahagiakan ummat sebagai tema pesan dakwah pokok dan utama sehingga dengan demikian pesan dakwahnya menjadi penting dan menunjang bagi kehidupan jamaah. Dari sini lahir konsep bahwa penetapan tema pesan dakwah itu haruslah tema-tema pesan dakwah yang penting dan menunjang bagi kehidupan dan kebutuhan jamaah. Kedua, Seorang dai dalam melakukan dakwah dapat menyajikan pesan dakwah, dengan sajian yang jelas dan sajian yang memberikan motivasi bagi jamaah dalam melaksanakan ajaran Islam yang diterimanya. Dari sini lahir konsep bahwa penyajian pesan dakwah harus berupa sajian yang jelas dan sajian yang memberi motivasi bagi diri jamaah. Ketiga, Seorang dai dalam melakukan dakwah dapat melakukannya dengan dakwah bil hikmah yaitu dakwah yang bijaksana (QS, An-Nahl, 16: 125). Qohthani (1994: 27) memahami hikmah sebagai metode dakwah itu ada dua: hikmah teoritis berupa dakwah mauidhah hasanah yang dalam perspektif komunikasi diknel dengan komunikasi penerangan; dan hikmah praktis berupa dakwah mujadalah ahsan yang dalam perspektif komunikasi dikenal dengan komunikasi penyuluhan. Dari sini lahir konsep dakwah hikmah dengan menggunakan metode dakwah penerangan dan metode dakwah penyuluhan secara proporsional. Keempat, Seorang dai dalam melakukan dakwah dapat memanfaatkan bentuk Komunikasi Antar-Persona, dakwah dengan bentuk Komunikasi Kelompok dan dakwah dengan bentuk Komunikasi Massa. Dari sini kemudian lahir konsep memanfaatkan bentuk-bentuk komunikasi secara tepat dan maksimal.

Bagaimana sebuah kegiatan dakwah dapat dilakukan secara baik dan tepat, Allah telah memberikan panduan proses dakwah secara garis besar dalam surat Al-Ahzab: 4546:Hai Nabi, Sesungguhnya kami mengutusmu untuk jadi saksi, dan pembawa kabar gemgira dan pemberi peringatan, dan untuk jadi penyeru kepada agama Allah dengan izin-Nya dan untuk jadi cahaya yang menerangi.(QS, AlAhzab, 33: 45-46). Berdasarkan ayat tersebut, salah satu langkah yang perlu dilakukan adalah seorang dai harus terlebih dahulu melakukan pengamatan sosial, sehingga dai sebagai pelaku dakwah menjadi orang yang tahu banyak (menjadi saksi-syahidan) tentang jamaahnya. Dengan pengetahuan yang banyak seorang dai akan mampu membuat dakwahnya menggembirakan, karena dakwah yang dilakukan memenuhi kebutuhan dan solusi hidup jamaah, umatnya. Hanya saja agar seorang dai benarbenar menjadi seorang saksi (syahidan), orang yang tahu banyak tentang umatnya, jamaahnya, audiensnya, maka seorang dai harus memiliki kemampuan minimal dalam tiga hal, dari empat kemampuan yang dipersyaratkan oleh Berlo (1960): (1) Kemampuan berkomunikasi sehingga seorang dai mampu dan trampil berempati dan berinteraksi dengan masyarakat sasarannya. (2) Kemampuan pengetahuan penyuluh sehingga seorang dai menjadi seorang yang tahu banyak tentang pesan yang disampaikan dan tahu banyak tentang masyarakat audiensnya berikut kendala yang muncul pada proses dakwah yang sedang berlangsung. (3) Kemampuan memahami sosial budaya masyarakat sehingga seorang dai akan mudah beradaptasi dengan sosial budaya masyarakatnya, seperti bahasa, keyakinan-agama, dan kebiasaan atau tradisinya (Mardikanto, 1993: 48-49).

Dari bahasan ini kemudian lahir konsep bahwa seorang dai harus kompeten minimal dalam tiga hal: (1) kompeten dalam berkomunikasi, (2) kompeten dalam hal pengetahuan mengenai pesan dan masyarakat audiensnya, serta (3) kompeten dalam memahami sosial budaya masyarakatnya. Berdasarkan kompetensi ini seorang dai akan dapat menetapkan tema pesan yang tepat, menyajikan pesan secara baik, menggunakan metode dakwah secara proporsional, dan memanfaatkan bentuk komunikasi secara tepat dan maksimal. Dengan pelaksanaan dakwah yang demikian ini dakwah yang dilakukan akan menjadi efektif dan berhasil. 
Upaya pengembangan konsep dakwah ini, tidak dapat mencukupkan dan berhenti pada pengembangan pemikiran konsep dakwah semata, tetapi juga diperlukan pengembangan pengukuran atas konsep dakwah yang ada. Oleh karena itu, konsep dakwah di atas perlu diuji dan diukur di lapanganpada aktivitas dakwah nyata.

Metode Penelitian ini dilakukan dengan survei terhadap 303 jamaah Kelompok Binaan (Pok-bin) dari 29 orang PAIF Kementrian Agama di 17 Kecamatan Kabupaten Sleman Daerah Istimewa Yogyakarta. Teknik pengumpulan data menggunakan dokumen, wawancara, observasi, dan kuesioner (Blaxter, 2001: 249). Metode yang digunakan mixed method yang merupakan rangkaian pendekatan kualitatif dan kuantitatif dalam suatu metodologi penelitian, dengan kajian dominan - kurang dominan (Tashakkori, 2010: 27-28). Pada kajian kuantitatif menjadi dominan pada analisis pengaruh kompetensi PAIF terhadap kegiatan dakwahnya dan pada analisis pengaruh kegiatan penyuluh terhadap efek yang diperoleh. Sedangkan kajian kualitatif, kurang dominan, dilakukan sebagai upaya mencari tahu lebih lanjut terhadap apa yang terjadi pada hasil kajian kuantitatif.

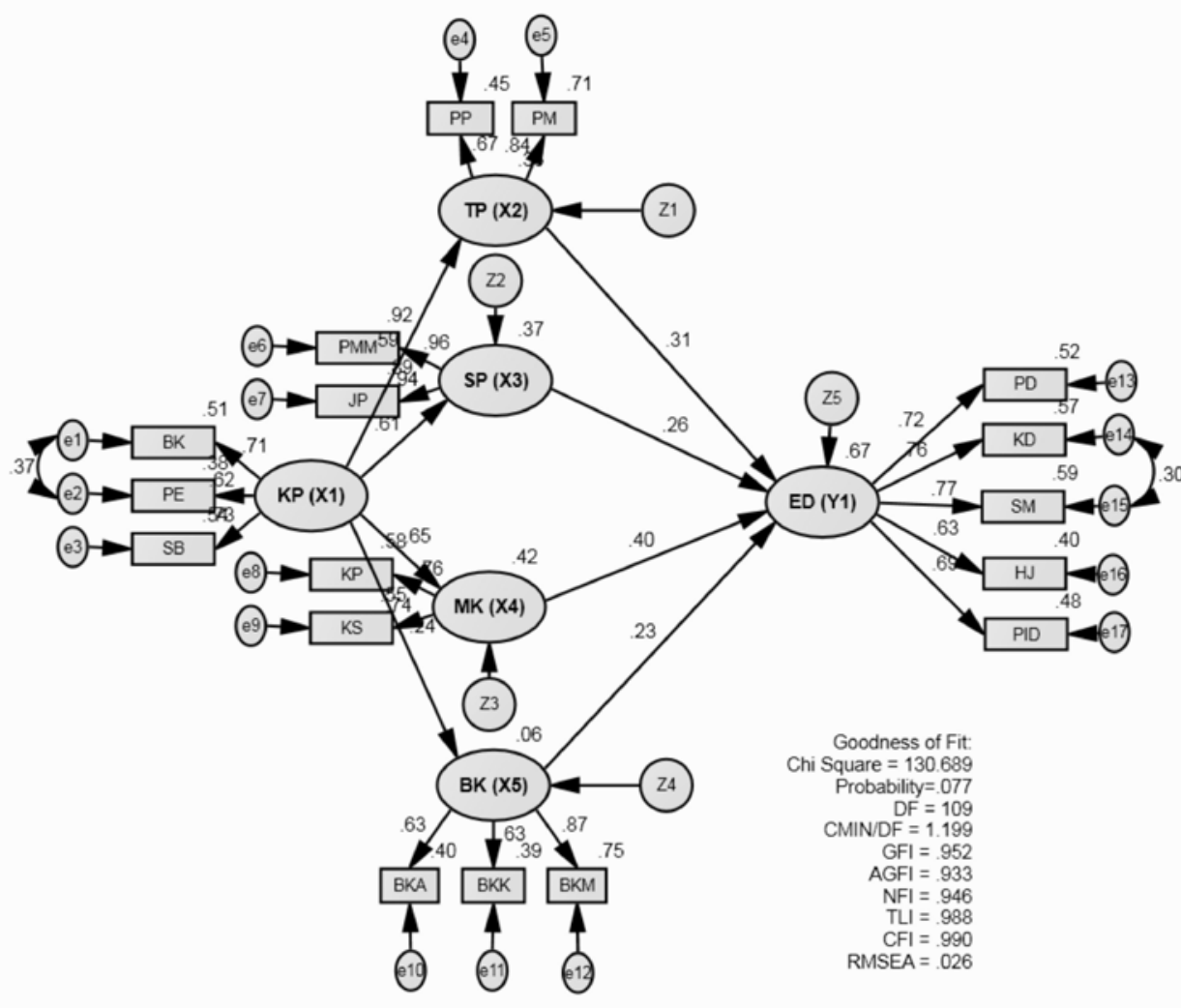

Gambar 1:

Hasil Analisis SEM Hubungan Antar Variabel Dakwah

Analisis data kuantitatif menggunakan teknik analisis SEM, analisis Structural Equation Modeling (model persamaan struktural) yang Maruyama (1998) menyebutnya sebagai sebuah model statistik yang memberikan perkiraan perhitungan dari kekuatan hubungan hipotesis di antara variabel dalam sebuah model teoritis, baik secara langsung atau melalui variabel antara (Mustafa \& Wijaya, 2012:1). Berdasarkan analisis SEM, hasil estimasi data penelitian dalam bentuk model struktural hubungan antar variabel dakwah yang dilakukan PAIF dalam membangun umat, nampak pada Gambar 1. 


\section{PEMBAHASAN}

Bahasan berikut merupakan upaya mengukur dan menguji konsep dakwah diatas dalam aktivitas dakwah nyata, yaitu pada kegiatan dakwah Islam yang dilakasanakan para PAIF Bimas Islam Kementrian Agama Kabupaten Sleman.

\section{Kompetensi PAIF dan Pengaruhnya}

Kompetensi PAIF sebagai seorang dai meliputi: kemampuan berkomunikasi, penguasaan pengetahuan, dan kemampuan sosial budaya. Berdasarkan skor tingkat keeratan indikator dari variabel Kompetensi para PAIF di Kabupaten Sleman, ketiga indikator tersebut mempunyai kontribusi yang cukup terhadap variabel Kompetensi Penyuluh: (1) Kemampuan berkomunikasi berkontribusi $50,6 \%$ bagi terjadinya kompetensi seorang penyuluh agama dalam melakukan dakwah. (2) Pengetahuan tentang pesan dan jamaah berkontribusi 38,2\% bagi terjadinya kompetensi seorang penyuluh agama dalam melakukan dakwah. (3) Kemampuan memahami sosial budaya berkontribusi $53,6 \%$ bagi terjadinya kompetensi seorang penyuluh agama dalam melakukan dakwah.

Tabel 1

Tingkat Keeratan dan Sumbangan pada Kompetensi Penyuluh

\begin{tabular}{l|l|l|l|l|l}
\hline \multicolumn{2}{c|}{ Indikator dan Variabel } & $\begin{array}{c}\text { Tingkat } \\
\text { keeratan }\end{array}$ & $\begin{array}{c}\text { Signifikansi } \\
(\mathbf{P})\end{array}$ & $\begin{array}{c}\text { Sumbangan } \\
\%\end{array}$ \\
\hline $\begin{array}{l}\text { Kemampuan } \\
\text { Berkomunikasi }\end{array}$ & $\rightarrow$ & $\begin{array}{l}\text { Kompetensi } \\
\text { Penyuluh }\end{array}$ & 0,711 & 0,000 & 50,6 \\
\hline $\begin{array}{l}\text { Pengtahuan tentang Pesan } \\
\text { dan Jamaah }\end{array}$ & $\rightarrow$ & $\begin{array}{l}\text { Kompetensi } \\
\text { Penyuluh }\end{array}$ & 0,618 & 0,000 & 38,2 \\
\hline $\begin{array}{l}\text { Kemampuan Memahami } \\
\text { Sos-Bud }\end{array}$ & $\rightarrow$ & $\begin{array}{l}\text { Kompetensi } \\
\text { Penyuluh }\end{array}$ & 0,732 & 0,000 & 53,6 \\
\hline
\end{tabular}

Sumber : Analisis Data Primer, 2014

Dengan demikian, kemampuan memehami sosial budaya (menggunakan bahasa, menghargai keyakinan, dan menghargai tradisi jamaahnya) dan kemampuan berkomunikasi (yang membuat dapat berempati \& berinteraksi) telah menempatkan pada posisi yang lebih penting (53,6\% dan $50,6 \%$ ) dibanding indikator Pengetahuan tentang pesan dan jamaah $(38,2 \%)$ dalam menentukan kompetensi seorang penyuluh agama. Artinya bahwa betapa seorang dai harus menjadi orang yang mampu memahami sosial budaya jamaahnya agar dia dapat berkomunikasi dengan baik sehingga dia menjadi orang yang mempunyai pengetahuan yang banyak dan mendalam tentang pesan dan jamaahnya. Seorang dai yang demikian ini nantinya akan dapat membuat pesan dakwah yang disampaikan menjadi pesan yang tepat dan berharga bagi jamaahnya.

Berdasarkan kenyataan ini, menjadi penting dan dapat dijadikan disain bagi pengambil kebijakan untuk mengupayakan pembinaan dai, dalam hal ini PAIF, dengan melakukan prioritas langkah-langkah berikut: (1) Mengembangkan kemampuan dai dalam memahami sosial budaya masyarakatnya; (2) Mengembangkan kemampuan dai dalam berkomunikasi; dan (3) Mengembangkan pengetahuan dai mengenai pesan dakwah dan realitas kebutuhan masyarakat. Berdasarkan dua pengembangan sebelumnya, pengembangan kemampuan dai dalam memahami sosial budaya masyarakat dan pengembangan kemampuan dai beradaptasi dalam berkomunikasi, kedua pengembangan tersebut akan mengantar dan mendukung seorang dai dalam mengembangkan pengetahuannya mengenai pesan dakwah yang terkait dengan realitas kebutuhan masyarakatnya berikut kendala yang dihadapi. Disain proses pengembangan kompetensi PAIF ini akan cukup nampak pada Gambar 2. 


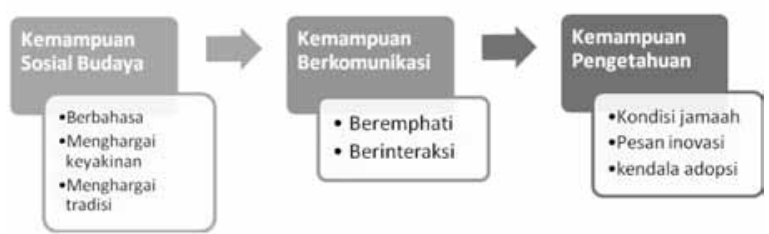

Gambar 2:

Pengembangan Kompetensi PAIF
Kompetensi seorang PAIF dengan tiga indikatornya sebagaimana telah dijelaskan sebelumnya, ketiga indikator tersebut akan mempengaruhi seorang PAIF dalam melakukan penetapan tema pesan, penyajian pesan, penggunaan metode dan pemanfaatan bentuk komunikasi pada kegiatan dakwah. Pengaruh kompetensi PAIF terhadap kegiatan dakwah yang dilaksanakan, secara ringkas disajikan pada tabel 2 .

Tabel 2

Pengaruh Kompetensi PAIF terhadap Kegiatan Dakwah yang Dilakukan

\begin{tabular}{l|l|l|l|l}
\hline \multicolumn{2}{c}{$\begin{array}{c}\text { Pengaruh Variabel Kompetensi pada } \\
\text { Variabel Kegiatan Dakwah }\end{array}$} & $\begin{array}{c}\text { Besar Pengaruh } \\
\text { Kompetensi }\end{array}$ & $\begin{array}{c}\text { Variabel } \\
\text { Lain }\end{array}$ \\
\cline { 3 - 5 } Kompetensi PAIF & $\rightarrow$ & Penetapan Tema Pesan & $35,0 \%$ & $65,0 \%$ \\
\hline Kompetensi PAIF & $\rightarrow$ & Penyajian Pesan & $36,9 \%$ & $63,1 \%$ \\
\hline Kompetensi PAIF & $\rightarrow$ & Penggunaan Metode & $42,4 \%$ & $57,6 \%$ \\
\hline Kompetensi PAIF & $\rightarrow$ & Pemanfaatan Bentuk Komunikasi & $5,7 \%$ & $94,3 \%$ \\
\hline
\end{tabular}

Sumber : Analisis Data Primer, 2014

Berdasarkan hasil analisis statistik yang tersaji pada bagian sebelumnya (Gambar 1), secara ringkas memperlihatkan sebagai berikut: (1) Kompetensi PAIF berpengaruh sebesar 35,0 \% pada kegiatan penetapan tema pesan yang dilakukan.(2) Kompetensi PAIF berpengaruh sebesar 36,9 \% pada kegiatan penyajian pesan yang dilakukan.

(3) Kompetensi PAIF berpengaruh sebesar $42,4 \%$ pada kegiatan penggunaan metode dakwah yang dilakukan.(4) Kompetensi PAIF berpengaruh sebesar 5,7 \% pada kegiatan pemanfaatan bentuk komunikasi yang dilakukan.

Pengaruh kompetensi PAIF cukup menonjol pada kegiatan penetapan tema pesan, penyajian pesan dan penggunaan metode, tetapi berpengaruh sangat kecil pada pemanfaatan bentuk komunikasi. Kenyataan ini bisa dipahami: di satu pihak, indikator bentuk komunikasi massa telah menentukan $75,4 \%$ dalam variabel pemanfaatan bentuk komunikasi dengan proporsi yang cukup besar, dominan, dan menentukan. Dakwah dengan bentuk Komunikasi massa seperti membagi-bagi buku, leaflet, selebaran, koran dan yang sejenis, bentuk komunikasi tersebut menjadi bagian dari bentuk komunikasi yang cukup membantu efektivitas kegiatan dakwah di masyarakat. Sementara di pihak lain, PAIF belum banyak dilatih dalam menggunakan media massa khusunya media cetak, sedangkan kegiatan dakwah yang sering dan terbiasa dilakukan baru memanfaatankan bentuk komunikasi kelompok, seperti yang dilakukan pada kelompok binaan. Berdasarkan kondisi inilah kompetensi PAIF tidak mampu memberikan pengaruh yang cukup besar pada pemanfaatan bentuk komunikasi, khusunya komunikasi massa cetak.

\section{Kegiatan Dakwah \\ Penetapan Tema Pesan Dakwah}

Penetapan tema pesan adalah upaya dai memberikan tema pesan atau materi dakwah agar menjadi sesui dengan kebutuhan jamaahnya. Penetapan tema pesan yang baik adalah penetapan pesan yang membuat pesan yang diterima oleh jamaahnya sebagai pesan penting dan pesan yang menunjang bagi upaya pemenuhan kebutuhan hidupnya. 
Tabel 3

Tingkat Keeratan Indikator atas Variabel Dakwah

\begin{tabular}{l|l|l|l}
\hline \multirow{2}{*}{$\begin{array}{c}\text { Variabel } \\
\text { Komponen Dakwah }\end{array}$} & \multicolumn{1}{c|}{ Indikator } & \multicolumn{2}{c}{ Penjelasan Indikator pada Variabel } \\
\cline { 2 - 4 } & & \multicolumn{1}{c}{ Keeratan } & \multicolumn{1}{c}{ Kontribusi } \\
\hline \multirow{2}{*}{ Penetapan Tema Pesan } & Pesan Penting & 0,670 & $44,9 \%$ \\
\cline { 2 - 4 } & Pesan Menunjang & 0,843 & $71,1 \%$ \\
\hline \multirow{2}{*}{ Penyajian Pesan } & Pesan Jelas & 0,943 & $89,0 \%$ \\
\cline { 2 - 4 } & Pesan Memotivasi & 0,960 & $92,1 \%$ \\
\hline \multirow{2}{*}{ Penggunaan Metode } & Komunikasi Penerangan & 0,763 & $58,1 \%$ \\
\cline { 2 - 4 } & Komunikasi Penyuluhan & 0,741 & $54,9 \%$ \\
\hline \multirow{2}{*}{$\begin{array}{l}\text { Pemanfaatan Bentuk } \\
\text { Komunikasi }\end{array}$} & Komunikasi Antarpribadi & 0,630 & $39,7 \%$ \\
\cline { 2 - 4 } & Komunikasi Kelompok & 0,627 & $39,3 \%$ \\
\cline { 2 - 4 } & Komunikasi Massa & 0,868 & $75,4 \%$ \\
\hline
\end{tabular}

Sumber : Analisis Data Primer, 2014; * Jumlah jamaah Pokbin / responden 303 orang

Berdasarkan hasil analisis statistik yang dilakukan menunjukkan bahwa indikator tema pesan yang penting berkontribusi hanya $44,9 \%$ pada variabel penetapan tema pesan dakwah; sedangkan indikator tema pesan yang menunjang berkontribusi $71,1 \%$. Dengan demikian, tema pesan yang menunjang telah menempatkan pada posisi yang lebih diutamakan $(71,1 \%$. > 44,9\%) dibanding tema pesan yang penting. Artinya bahwa betapa seorang dai dalam menetapkan tema pesan harus dapat mengutamakan pesan yang menunjang kebutuhan jamaahnya dari pada pesan yang sekedar penting. Pesan yang menunjang, pesan dakwah yang memperluas pemahaman mengenai kebutuhan yang dirasakan jamaahnya harus lebih diutamakan dari pada pesan yang penting, pesan dakwah yang sekedar berisi dasar pemahaman mengenai kebutuhan yang dirasakan.

Fakta kajian terkait aktivitas yang dilakukan oleh PAIF di lapangan (persepsi jamaah) menunjukkan penetapan tematema pesan peting lebih diutamakan dari pada tema-tema pesan yang menunjang. Hal ini terlihat pada apa yang dirasakan jamaah di lapangan. Sebagian besar jamaah $(93,7 \%)$ memiliki penilaian bahwa para PAIF mempunyai kemampuan yang tinggi dalam menetapkan tema pesan dakwah yang penting, sementara itu proporsi yang lebih rendah $(90,1 \%)$ jamaahnya menilai bahwa PAIF mempunyai kemampuan yang tinggi dalam menetapkan tema pesan yang menunjang bagi kehidupan jamaahnya. Seorang dai harus dapat menetapkan tematema pesan dakwah yang penting. Akan tetapi untuk mempermudah aplikasi pesan dalam kehidupan nyata, jamaah membutuhkan pesan yang memperkaya pemahamannya. Disinilah materi penunjang diutamakan.

Beberapa cara yang dapat ditempuh misalnya dengan menghadirkan film, sinetron dan bentuk cerita lain yang berisi bagaimana meraih pemenuhan kebutuhan sehingga akan mempermudah mewujudkan pemenuhan kebutuhan yang dirasakan. “... kita melihat bagaimana tontonan -saat telah menjadi realitas sosial yang sangat terlihatjustru pengaruhnya terhadap perilaku sosial tidak begitu terlihat. Pengaruh ini tetap nyata dalam wacana spesifik, yang menyediakan kasus-kasus langka di mana bidang rekognisi yang dibuat oleh medium broadcast mengembun jadi isi dari medium tersebut" (Holmes, 2012: 76).

\section{Penyajian Pesan Dakwah}

Penyajian pesan merupakan upaya seorang dai bagaimana pesan disajikan kepada jamaahnya dapat dimengerti dan dipahami dengan jelas dan memberikan motivasi pada penerima/target audiens yaitu jamaahnya. Penyajian pesan yang baik adalah penyajian pesan yang membuat pesan yang diterima sebagai pesan yang jelas dan pesan yang memberikan motivasi 
bagi jamaahnya dalam proses pemenuhan kebutuhan hidupnya.

Berdasarkan hasil analisis statistik (lihat tabel 3) secara garis besar menunjukkan bahwa: indikator pesan yang jelas berkontribusi $89,0 \%$ pada variabel penyajian pesan dakwah; sedangkan indikator pesan yang memberikan motivasi berkontribusi 92,1\%. Pesan yang memberikan motivasi telah menempatkan pada posisi yang lebih diutamakan $(92,1 \%>89,0 \%)$ dibanding pesan yang jelas. Artinya bahwa betapa seorang dai dalam menyajikan pesan harus dapat mengutamakan pesan yang memberikan motivasi bagi jamaah dalam usaha memenuhi kebutuhannya dari pada pesan yang sekedar memberikan penjelasan semata.

Realitas data lapangan (persepsi jamaah) memperlihatkan bahwa para PAIF mempunyai kemampuan yang tinggi dalam menyajikan pesan dakwahnya, sehingga pesannya menjadi jelas $(90,1 \%)$ dan menimbulkan motivasi $(90,1 \%)$ bagi jamaahnya. Penyajian pesan dakwah yang jelas akan menjadikan jamaahnya mengetahui: apa, bagaimana, dan kapan melakukan sesuatu serta mengetahui hasil apa yang akan diperoleh. Penyajian pesan dakwah yang memberi motivasi adalah pesan yang mampu membuat isi pesannya menjadi: relevan, menarik, dapat dipraktekkan, dan menguntungkan bagi kehidupan jamaahnya serta dipercaya bahwa apa yang harus dilakukan itu sesuatu yang baik dan perlu.

Bagaiamana pesan menjadi jelas dan bermotivasi ini tidak lepas dari kemampuan seorang dai dalam memahami sosial budaya masyarakatnya, sebagaimana dipersyaratkan oleh Wilbur Schramm (Kholili, 2009: 28) dalam menyiapkan pesan. Oleh karena, seorang dai yang demikian ini akan dengan mudah membuat pesan dakwahnya "membangkitkan kebutuhan pribadi pihak sasaran dan menyarankan beberapa cara untuk memperoleh kebutuhannya"; dan juga seorang dai akan dengan mudah membuat pesan dakwahnya "menyarankan suatu jalan untuk memperoleh kebutuhan tadi, yang layak bagi situasi kelompok (tradisi- budaya) di mana sasaran berada pada saat ia digerakkan untuk memberikan tanggapan yang dikehendaki".

\section{Penggunaan Metode Dakwah}

Metode dakwah adalah cara-cara tertentu dalam menyampaikan pesan yang dilakukan untuk mencapai suatu tujuan atas dasar hikmah: "mauidhah hasanah" dengan komunikasi penerangan dan "mujadalah ahsan" dengan komunikasi penyuluhan. Berdasarkan hasil analisis statistik yang dilakukan pada penelitian ini, indikator komunikasi penerangan berkontribusi $58,1 \%$, sedangkan indikator komunikasi penyuluhan berkontribusi $54,9 \%$ pada proses penggunaan metode dakwah yang dilakukan seorang penyuluh agama, PAIF.

Dengan demikian, metode dakwah "mauidhah hasanah" dengan komunikasi penerangan telah menempatkan pada posisi yang sedikit lebih diutamakan $(58,1 \%>54,9 \%)$ dibanding dengan metode dakwah "mujadalah ahsan" dengan komunikasi penyuluhan. Artinya bahwa betapa seorang dai dalam menggunakan metode dakwah harus dapat mengutamakan penggunaan metode dakwah komunikasi penerangan dalam usaha memenuhi kebutuhan jamaahnya, yang kemudian diimbangi dengan penggunaan metode dakwah komunikasi penyuluhan.

Penerangan "hanya" merupakan upaya menyampaikan pesan kepada masyarakat supaya menjadi tahu dan sadar akan adanya sesuatu (Subejo, 2012), yang prakteknya banyak menggunakan media massa dalam bentuk siaran seperti radio dan televisi, yang orientasinya cenderung kuat satu arah (Amri Jahi, 1993: 126-131) dan bersifat informatif. Informasi dapat membantu segmen-segmen pemakai itu mengetahui isu-isu yang harus mereka hadapi dan dapat membantu mereka memahami alternatif-alternatif yang tersedia.

Akan tetapi, hanya dengan informasi, mereka tidak akan mampu mengubah situasi yang dihdapi (Baltran, 1976; Grung, 1975, dalam Gonzalez, 1993: 59). "Saluransaluran interpersonal dapat melengkapi upaya mencapai khalayak melalui media 
massa sebelum, selama, dan setelah (dakwah penerangan yang bersifat) kampanye" (Chu, 1977; Schramm, 1984). Dan, “... interaksi (keseimbangan) komunikasi interpersonal dan komunikasi massa dalam (dakwah) kampanye pembangunan sangat berharga" (Rogers dan Agarwala-Rogers, 1976; Rogers dan Kincaid, 1981; Rogers dan Kim, 1985) dalam Gonzalez (1993: 66). Oleh karena itu, Hovland mengatakan bahwa pesan komunikasi massa efektif dalam menyebarkan informasi, tetapi tidak dalam mengubah perilaku (Effendy, 2003: 265).

Dengan memperhatikan kelemahan komunikasi penerangan, maka diketahui pentingnya dan keunggulan aspek dan pemanfaatan komunikasi penyuluhan pada kegiatan dakwah. Oleh karena, “...dalam prakteknya, "penerangan" dapat merupakan tahap awal penyuluhan. Penyuluhan mempunyai tujuan lebih jauh yaitu sampai dengan menimbulkan hasrat atau keinginan dari penerima pesan (sasaran) penyuluhan yang dengan kesadarannya sendiri tanpa paksaan melakukan penilaian sehingga tumbuh keyakinan kemudian mencoba dan selanjutnya menerapkan pesan atau informasi dan atau pengetahuan yang diterimanya" (Subejo, 2012).

Terkait dengan upaya menyeimbangkan antara penggunaan metode dakwah komunikasi penerangan dengan metode dakwah komunikasi penyuluhan, realitas di lapangan (persepsi jamaah) memperlihatkan bahwa sebagian besar $(79,5 \%)$ jamaah menganggap para PAIF dapat menggunakan metode penerangan dengan kemampuan tinggi, hanya sebagian kecil saja (20,5\%) jamaah yang menganggap para PAIF dapat menggunakan metode penerangan dengan kemampuan sedang. Berbeda pada penggunaan metode penyuluhan, sebaagian besar $(65,0 \%)$ jamaah menganggap para PAIF dapat menggunakan metode penyuluhan dengan kemampuan sedang, hanya sebagian kecil saja $(27,1 \%)$ jamaah yang menganggap para PAIF dapat menggunakan metode penyuluhan dengan kemampuan tinggi.
Berdasarkan realitas ini, para PAIF perlu terus berupaya menyeimbangkan penggunaan metode dakwah komunikasi penerangan dan metode dakwah komunikasi penyuluhan, baik secara kualitas maupun kuantitas. Ketidakseimbangan penggunaan metode dakwah ini cukup nampak pada pemanfaatan bentuk komunikasi, sebagaiman akan dibahas di bawah ini; dan juga akan melahirkan sumbangan yang kecil pada efek dakwah, sebagaimana dibahas pada bagian berikutnya.

\section{Pemanfaatan Bentuk Komunikasi}

Pemanfaatan bentuk komunikasi yang dimaksud adalah bentuk komunikasi yang dimanfaatkan PAIF pada kegiatan dakwah yang dilakukan bagi jamaah kelompok binaannya. Bentuk komunikasi yang digunakan bisa berupa Komunikasi antarpribadi (interpersonal), Komunikasi kelompok dan Komunikasi massa khusunya media cetak. Berdasarkan hasil analisis statistik yang dilakukan pada penelitian ini, komunikasi massa berkontribusi $75,4 \%$ pada proses pemanfaatan bentuk komunikasi yang dilakukan seorang PAIF; sedangkan indikator komunikasi antarpribadi dan indikator komunikasi kelompok masing-masing hanya berkontribusi 39,7\% dan 39,3\%.

Dengan demikian, bentuk komunikasi massa telah menempatkan pada posisi yang lebih diutamakan $(75,4 \%)$ dari pada komunikasi antarpribadi (39,7\%) dan komunikasi kelompok (39,3\%). Kondisi ini menjelaskan bahwa betapa seorang dai dalam memanfaatakan bentuk komunikasi sangat diharapkan dapat memperbanyak menggunakan bentuk komunikasi massa dari pada komunikasi kelompok dan komunikasi antar pribadi. Devito (1997: 516) menjelaskan bahwa salah satu cara mendidik (atau mempersuasi) adalah melalui pengajaran nilai-nilai, opini, serta aturan-aturan yang dianggap benar kepada pemirsa atau pembaca. Artinya, sebagian fungsi dari edukasi media diarahkan untuk membuat khalayak tersosialisasi. Mereka 
melakukannya dalam drama, cerita, diskusi, artikel, komik, dan iklan-iklan. Dalam semua situasi ini, nilai-nilai masyarakat diungkapkan secara tidak dikatakan.

Terkait dengan seberapa sering seorang PAIF memanfaatkan bentuk komunikasi secara tepat dan seimbang pada kegiatan dakwah, maka sebagian besar $(97,1 \%)$ jamaah mengalami bahwa frekuwensi PAIF dalam memanfaatkan bentuk komunikasi massa berada pada tingkat pemanfaatan yang sangat rendah. Demikian juga yang terjadi pada pemanfaatan bentuk komunikasi kelompok dan bentuk komunikasi antarpribadi, dalam mana sebagian besar jamaah $(85,1 \%$ dan $79,5 \%)$ mengalami hal yang sama bahwa pemanfaatan kedua bentuk komunikasi tersebut berada pada tingkat yang rendah.

Kenyataan ini berbeda dari yang seharusnya terjadi, khususnya dalam pemanfataan bentuk komunikasi masaa. Hasil analisis statistik memperlihatkan bahwa komunikasi massa berkontribusi $75,4 \%$ pada proses pemanfaatan bentuk komunikasi yang dilakukan seorang penyuluh; maka sudah seharusnya seorang dai lebih banyak memanfaatakan bentuk komunikasi massa tersebut dari pada komunikasi kelompok $(39,3 \%)$ dan komunikasi antar-pribadi $(39,7 \%)$. Prakteknya justru sebagian besar $(97,1 \%)$ penyuluh sangat rendah dalam memanfaatkan bentuk komunikasi massa.

Berdasarkan beberapa temuan di atas, maka menjadi penting untuk merancang strategi dakwah tingkat Nasional, Regional dan lokal yang komprehensif dengan

langkah-langkah: (1) Mengembangkan dakwah bil hikmah dengan membagi, mengembangkan, dan menyeimbangkan dakwah penerangan, dan dakwah penyuluhan. Kebijakannya dakwah penerangan dipegang dan dilaksanakan oleh Direktur Penerangan Agama Islam (Kemenag Pusat), Bidang Penerangan Agama Islam (Kemenag Wilayah), dan Seksi Bimas Islam (Kemenag Kabupaten/ Kota). Dakwah penyuluhan sebagai kelanjutan dan bentuk ekskusi dari pesan dakwah penerangan yang ada, dilaksanakan oleh para PAIF di Kecamatan di bawah koordinasi Seksi Bimas Islam Kemenag Kabupaten. (2) Mendahulukan pesan dakwah dengan sajian yang memberikan motivasi bagi jamaahnya sehingga mempunyai relevansi dan berguna bagi pemenuhan kebutuhan hidupnya. (3) Mengutamakan penetapan topik pesan yang menunjang bagi kebutuhan masyarakatnya dari pada tema pesan yang sekedar penting untuk diketahui. (4) Memaksimalkaan pemanfaatan secara tepat bentuk-bentuk komunikasi massa, komunikasi antarpribadi, dan komunikasi kelompok dalam pelaksanaan dakwah penerangan dan dakwah penyuluhan.

\section{Efektivitas dan Efek Dakwah Efektivitas Dakwah}

Kegiatan dakwah Islam oleh PAIF, pada tulisan ini, meliputi komponen: penetapan tema pesan, penyajian pesan, penggunaan metode, dan pemanfaatan bentuk komunikasi. Keempat komponen tersebut masingmasing dan secara bersama akan mempengaruhi efektivitas kegiatan dakwah.

Tabel 4

Pengaruh Komponen Kegiatan Dakwah pada Efek Dakwah

\begin{tabular}{l|c|l|l|c}
\hline \multirow{2}{*}{$\begin{array}{c}\text { Pengaruh Variabel Komponen Dakwah pada Variabel Efek } \\
\text { Dakwah }\end{array}$} & \multicolumn{2}{c}{ Besar Pengaruh } \\
\cline { 4 - 5 } \multicolumn{2}{l}{$\begin{array}{c}\text { Variabel } \\
\text { Dakwah }\end{array}$} & $\begin{array}{c}\text { Variabel } \\
\text { Lain }\end{array}$ \\
\hline Penetapan Tema Pesan & $\rightarrow$ & Efek Dakwah & $9,61 \%$ & $90,39 \%$ \\
\hline Penyajian Pesan & $\rightarrow$ & Efek Dakwah & $6,60 \%$ & $93,40 \%$ \\
\hline Penggunaan Metode & $\rightarrow$ & Efek Dakwah & $15,68 \%$ & $84,32 \%$ \\
\hline Pemanfaatan Bentuk Komunikasi & $\rightarrow$ & Efek Dakwah & $5,24 \%$ & $94,76 \%$ \\
\hline
\end{tabular}

Sumber : Analisis Data Primer, 2014 
Berdasarkan hasil analisis statistik seperti tersaji pada tabel 4 memperlihatkan sebagai berikut: (1) Penetapan Tema Pesan berpengaruh sebesar 9,61\% pada efek dakwah; sedangkan selebihnya (90,39\%) ditentukan oleh faktor lain. (2) Penyajian Pesan berpengaruh sebesar 6,60\% pada efek dakwah; sedangkan selebihnya (93,40\%) ditentukan oleh faktor lain. (3) Penggunaan metode berpengaruh sebesar $15,68 \%$ pada efek dakwah; sedangkan selebihnya $(84,32 \%)$ ditentukan oleh faktor lain. (4) Pemanfaatan bentuk komunikasi berpengaruh sebesar $5,24 \%$ pada efek dakwah; sedangkan selebihnya $(94,76 \%)$ ditentukan oleh faktor lain. Kemudian empat komponen kegiatan dakwah di atas secara bersama mempengarui Efek dakwah sebesar $66,9 \%$, pengaruh yang cukup besar; sedangkan sisanya $(33,1 \%)$ dipengaruhi oleh variabel lain.

Ketika melihat pengaruh masing-masing komponen kegiatan dakwah terhadap efek dakwah, masing-masing kegiatan hanya berpengaruh di bawah $20 \%$, pengaruh yang sangat kecil. Kenyataan ini bisa dipahami dan harus dicermati. Masing-masing komponen kegiatan bukanlah kegiatan yang berdiri sendiri, tetapi satu kesatuan dan saling terkait satu dengan yang lain. Penetepan tema pesan tidak dapat berpengaruh tanpa pesan itu disajikan. Penyajian pesan tidak akan banyak berpengaruh tanpa ditunjang pemanfaatan bentuk komuniksi secara tepat dan maksimal dari tiga bentuk komunikasi yang ada. Demikian juga, penggunaan metode dakwah yang seimbang antara metode penerangan dan metode penyuluhan tidak akan memberikan banyak pengaruh tanpa didukung oleh tiga komponen dakwah yang lain: penetapan tema pesan, penyajian pesan, dan pemanfaatan bentuk komuniksi. Ketika keempat komponen kegiatan dakwah itu bekerja bersama, maka secara bersama memberikan pengaruh yang besar pada efek dakwah, dengan efek sebesar $66,9 \%$, efek yang cukup besar.

Komponen dakwah dilihat secara terpisah dimaksudkan untuk mengetahui dan mengevaluasi secara rinci proses dan pengaruh masing-masing komponen kegiatan dakwah sehingga dapat lebih rinci pula dalam mengembangkan masing-masing komponen menjadi komponen dakwah yang memberikan efek yang maksimal sebagaimana telah ditargetkan.

\section{Efek Dakwah}

Efek Dakwah adalah pencapaian (output) dari kegiatan dakwah yang berupa: pengertian, kesenangan, sikap, hubungan sosial, dan tindakan terhadap pesan Islam yang diterima.

Tabel 5

Tingkat Keeratan dan Sumbangan pada Efek Dakwah

\begin{tabular}{llll}
\hline Indikator dan Variabel & Tingkat keeratan & Signifikansi $(\mathrm{P})$ & Sumbangan $\%$ \\
\hline Pengertian $\rightarrow$ Efek Dakwah & 0,722 & 0,000 & 52,1 \\
\hline Kesenangan $\rightarrow$ Efek Dakwah & 0,758 & 0,000 & 57,5 \\
\hline Sikap $\rightarrow$ Efek Dakwah & 0,765 & 0,000 & 58,5 \\
\hline Hubungan sosial $\rightarrow$ Efek Dakwah & 0,630 & 0,000 & 39,7 \\
\hline Tindakan $\rightarrow$ Efek Dakwah & 0,692 & 0,000 & 48,0 \\
\hline
\end{tabular}

Sumber : Analisis Data Primer, 2014

Efek dakwah didukung oleh indikator, yaitu indikator pengertian yang mempunyai tingkat keeratan 0,722 dengan kontribusi $52,1 \%$; indikator kesenangan yang mempunyai tingkat keeratan 0,758 dengan kontribusi 57,5\%; indikator sikap yang mempunyai tingkat keeratan 0,765 dengan kontribusi 58,5\%; indikator hubungan sosial yang mempunyai tingkat keeratan 0,630 dengan kontribusi 39,7\%; dan didukung pula oleh indikator tindakan yang mempunyai tingkat keeratan 0,692, dengan kontribusi 48,0\% (lihat Tabel 5). Artinya bahwa, efek dakwah yang ada ini melibatkan 52,1\% dari 
indikator pengertian; melibatkan $57,5 \%$ dari indikator kesenangan; melibatkan 58,5 \% dari indikator sikap; melibatkan 39,7\% dari indikator hubungan sosial; dan melibatkan $48,0 \%$ dari indikator tindakan.

Hasil kajian memperlihatkan bahwa indikator kesenangan (57,5\%) dan indikatorsikap (58,5\%) merupakan indikator yang paling menonjol pada kemunculan sebuah efek dakwah, selain indikator pengertian, hubungan sosial dan tindakan. Artinya betapa bahwa sebuah efek dakwah yang dikehendaki adalah efek dakwah yang menimbulkan kesenangan dan sikap suka dari jamaahnya.

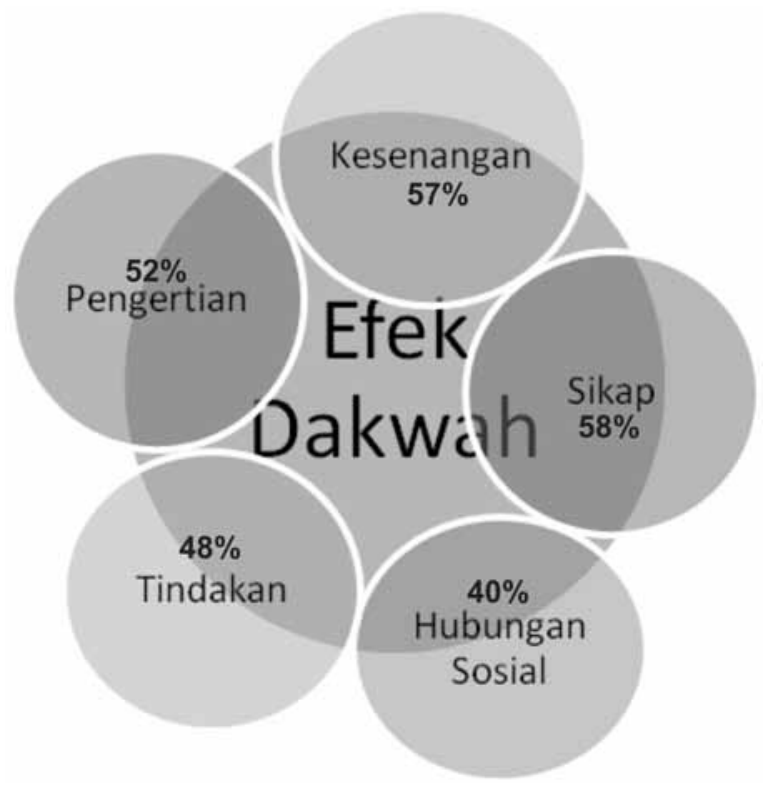

Gambar 3

Kontribusi Lima Indikator Efek Dakwah

Berdasarkan hasil penelitian ini, telah nampak dan membuktikan apa yang dimaksudkan oleh ayat 28 Surat Saba bahwa kedatangan Islam yang rahmat (rahmatan) itu tentu akan merupakan berita gembira (basyiran) yaitu Islam yang menghadirkan kesenangan dan rasa suka bagi seluruh manusia, khususnya manusia yang menjadi target audiensnya, hanya saja kebanyakan manusia tiada mengetahui.Ketidaktahuan ini dapat terjadi oleh karena tidak ada orang yang memberi tahu (berdakwah); atau ada orang yang memberi tahu, tetapi tidak bisa melakukan bagaiamana cara memberi tahu yang baik dan benar yang dapat menggembirakan bagi seluruh manusia, khususnya manusia yang menjadi target audiensnya. Oleh karena itu, Islam akan diterima oleh terget audiensnya manakala Islam yang hadir adalah Islam yang rahmat, rahmatan lil 'alamin (QS, Al-Ambiyaa, 21: 107) yaitu Islam yang memberikan manfaat bagi kehidupan manusia, kehidupan yang sejahtera lahir batin, sehingga kehadiran Islam merupakan berita gembira, basyiran (QS, Saba, 34: 28),Islam yang menyenangkan dan disambut dengan rasa suka cita.

Mendasarkan pada efektivitas dakwah dengan menggunakan konsep efektivitas komunikasi yang meliputi munculnya: pengertian, kesenangan, sikap, hubungan sosial dan tindakan terhadap pesan Islam yang diterima, maka kegiatan dakwah hendaknya diarahkan kepada upaya pemenuhan kebutuhan dan solusi hidup jamaahnya, sehingga akan muncul efektivitas dakwah yang menghasilkan kesenangan dan sikap positif pada diri jamaah terhadap pesan dakwah yang disampaikan seorang dai.

\section{SIMPULAN}

Pertama, Hasil analisis SEM atas data lapangan, menunjukkan tiga kompetensi seorang dai memperlihatkan: kemampuan memahami sosial budaya dan kemampuan berkomunikasi memosisikan lebih besar kontribusinya dibandingkan kemampuan pengetahuan.Analisis mendasarkan pada kerangka teori Analisis Proses Interaksi dari Bales,dengan penekanan kemampuan memahami sosial budaya menjadi bagian awal yang harus dilakukan, maka teori kompetensi yang disampaikan Berlo menjadikan seorang dai dituntut menjadi orang yang mampu memahami sosial budaya jamaahnya agar mereka dapat berkomunikasi dengan baik sehingga mereka menjadi orang yang mempunyai pengetahuan yang banyak dan mendalam tentang kondisi jamaahnya. Berdasarkan kemampuannya ini, menurut Schramm, seorang dai akan dengan mudah menyarankan suatu jalan untuk memperoleh 
dan memenuhi kebutuhan yang layak bagi situasi kelompok,budaya masyarakat di mana jamaah berada. Dengan demikian betapa seorang dai memang harus menjadi saksi, syahidan, orang yang mengetahui banyak tentang umatnya sebagaimana dijelaskan dalam al-Qur'an surat Al-Ahzab ayat $45-46$.

Kedua, Variabel Kompetensi PAIF berpengaruh secara signifikan dengan sumbangan yang cukup besar terhadap variabelvariabel penetapan tema pesan, penyajian pesan dan penggunaan metode dakwah. Demikian juga, variabel Kompetensi PAIF berpengaruh secara signifikan terhadap pemanfaatan bentuk komunikasi pada kegiatan dakwah yang dilakukan para PAIF tetapi dengan sumbangan yang masih relatif kecil. Variabel kompetesi mempunyai pengaruh yang cukup besar terhadap penggunaan metode dakwah melebihi yang lain, sementara variabel kompetesi mempunyai pengaruh yang sangat kecil pada pemanfaatnan bentuk komunikasi. Realitas ini dapat dipahami karena para PAIF dibina cukup intens pada kemampuannya dalam melaksanakan dakwah penerangan dan dakwah penyuluhan; sementara para PAIF belum dibina secara maksimal pada kemampuannya dalam memanfaatkan bentuk komunkasi, khususnya bentuk komunikasi massa dengan media cetak.

Ketiga, Kegiatan dakwah yang meliputi variabel-variabel penetapan tema pesan dakwah, penyajian pesan dakwah, penggunaan metode dakwah dan pemanfaatan bentuk komununikasi berpengaruh secara signifikan dengan sumbangan yang cukup variatif terhadap variabel efek dakwah. Berdasarkan sumbangan yang diberikan oleh masing-masing variabel kegiatan dakwah, diketahui variabel yang paling berpengaruh bagi munculnya efek dakwah adalah variabel penggunaan metode dakwah yaitu dakwah penerangan dan dakwah penyuluhan. Namun demikian secara keseluruhan variabel kegiatan dakwah, seluruh variabel tersebut secara bersama telah mempengarui Efek dakwah dengan proporsi yang cukup besar (67\%). Sedangkan sisanya efektivitas dakwah dipengaruhi oleh variabel lain.

\section{DAFTAR PUSTAKA}

Departemen Agama RI. 1993. Al-Qur'an dan Terjemahnya. Terjemah Yayasan Penyelenggara Penterjemah AlQur'an.Depatemen Agama RI. Jakarta.

Berlo, D. K. 1960.The Process of Communication, An Introduction to Theory and Practice. Editorial El Ateneo. New York.

Blaxter, L., C. Hughes dan M. Thight.2001.How to Research. Second Edition. SAGE. London.Terjemah S.Agustina.2001. How to Research.Seluk-belukMelakukan Riset.Edisi kedua.Indeks.Jakarta.

Depag DIY. 2005.Buku Pedoman Penyuluh Seri II.Bidang Pendidikan Agama Islam pada Masyarakat dan Pembedayaan Masjid.Kanwil Departemen Agama Prop. DI Yogyakarta

Devito, J. A. 1996.Human Communication. Haper Collins. New York. Terjemah A. Maulana. 1997. Komunikasi Antar Manusia.Edisi kelima.Professional Books.Jakarta.

Effendy, O. U. 1986.Ilmu Komunikasi. Teori dan Praktek. Remdja Karya. Bandung.

Gonzalez, H. 1993.Beberapa Mitos Komunikasi dan Pembangunan.Dalam Komunikasi Massa dan Pembangunan Pedesaan di Negara-negara Dunia Ketiga.Editor A. Jahi. Garamedia. Jakarta.

Holmes, D. 2005.Communication Theory: Media, Technology, and Society.SAGE. New Delhi and singapore. Terjemah T. W. Utomo. 2012.Teori Koumunikasi: Media, Teknologi dan Masyarakat. Pustaka Pelajar. Yogyakarta.

Jahi, A. 1993.Media Siaran dalam Pembangunn Pedesaan di Negara-negara Dunia Ketiga.Dalam Komunikasi Massa dan Pembangunan Pedesaan di Negaranegara Dunia Ketiga.EditorA. Jahi. Gramedia Pustaka Utama. Jakarta. 
Litlejohn, S.W.\& K. A.Foss. 2008.Teories of Human Communication.Ninth Edition. Thomson Wadsmorth. USA.

Kholili, H.M. 2009.Komunikasi untuk Dakwah, Suatu Pengantar. Amanah. Yogyakarta.

Mantra, I.B. \& Hasto.1992.Penentuan Sampel. Dalam Metode Penelitan Survi.Editor M. Singarimbun. LP3ES. Jakarta.

Mardikanto, T.1993. P e n y u $l$ u $h a n$ Pembangunan Pertanian. Sebelas Maret Univercity Press. Surakarta.

MUI Sleman. 2005.Peta Dakwah Kabupaten Slema.MUI Sleman. Sleman

Mustafa, Z.dan T. Wijaya. 2012.Panduan Teknik Statistik SEM \& PLS dengan SPSS Amos. Cahaya Atma Pustaka. Yogyakarta

Qohthani, S. A.1994.Al-Hikmah fi Da'wah ila Allah Ta'ala. Terjemah M. Hakim.
1994. Da'wah Islam Da'wah Bijak. Gema Insani Press. Jakarta.

Subejo. 2012.Bahan Kuliah Dasar-dasar Penyuluhan dan Komunikasi Pertanian.Fakultas Pertanian UGM. Yogyakarta.

Suisyanto. 2006.Pengantar Filsafat Dakwah. Teras.Jogjakarta.

Tashakkori, A.\&C.Teddlie.1998. Mixed Methodology, Combining Qualitaive and Quantitative Approaches. SAGE. California.Terjemah B.P.Priadi. 2010. Mixed Methodology. Mengombinasikan Pendekatan Kualitatif dan Kuantitatif. Pustaka Pelajar. Jogjakarta.

West, R.\&L. H.Turner. 2007.Introducing Communication Theory: Analisys and Aplication. $3^{\text {rd }}$ ed. McGraw-Hill. New York. Terjemah M. Natalia DM. 2008. Pengantar Teori Komunikasi. Edisi 3. Analilis dan Aplikasi. Salemba Humanika. Jakarta. 